\title{
IMPLEMENTASI PELATIHAN E-LEARNING ERA PANDEMIK
}

\author{
Elsy Zuriyani ${ }^{1}$, Miskiah $^{2}$ \\ ${ }^{1}$ Balai Diklat Keagamaan Palembang, Kementerian Agama, Palembang \\ ${ }^{2}$ Balai Diklat Keagamaan Palembang, Kementerian Agama, Palembang \\ elsyzuriyani@gmail.com; ${ }^{2}$ miskiahpahrul@yahoo.co.id
}

\begin{abstract}
Abstrak
Dengan adanya Pandemik COVID-19 ini maka semua aktifitas yang ada di perkantoran negeri maupun swasta berubah. Pandemik ini bukan saja terjadi di Indonesia tetapi seluruh negara. Pandemik ini mengharuskan setiap orang harus menjaga jarak agar tidak bersentuhan dengan orang yang bisa menyebabkan virus COVID-19 menular. Oleh karena itu Balai Diklat Keagamaan Palembang juga menyesuaikan sistem pelatihannya dari konvensional dirubah menjadi pelatihan secara e-learning. Penelitian implementasi pelatihan e-learning ini bertujuan untuk mengetahui bagaimana pelaksanaan pelatihan e-learning dibalai diklat keagaman Palembang dan juga mengetahui apa faktor penghambat dan pendukung pelatihan secara e-learning. Dalam penelitian kali ini peneliti menggunakan metode penelitian kualitatif deskriptif. Dan hasil yang diperoleh balai diklat keagamaan Palembang telah melaksanakan pelatihan berbasis $e$ learning dengan tahapan sebagai berikut perencanaan, pengorganisasian, pelaksanaan dan evaluasi pelatihan secara e-learning. Untuk faktor penghambat ada tiga faktor yaitu pengetahuan peserta pelatihan tentang IT, jaringan internet dan motivasi dan komitmen peserta pelatihan. Sedangkan faktor pendukung adalah adanya persiapan yang dilakukan Balai Diklat Keagamaan Palembang terhadap panitia dengan widyaiswaranya terhadap pelaksanaan pelatihan e-learning, tersedianya jaringan Wifi di Balai Diklat Keagamaan Palembang, adanya uang penggantian kuota untuk peserta pelatihan, widyaiswara dan panitia serta perkembangan zaman yang mendukung pelaksanaan pelatihan berbasis e-learning. Dari hasil penelitian dapat disimpulkan Balai Diklat Keagaman Palembang telah melaksanakan pelatihan e-learning dengan adanya beberapa faktor penghambat dan pendukung kesuksesan pelaksanaan pelatihan berbasis e-learning.
\end{abstract}

Kata kunci: Pelatihan, E-learning, Pandemik 


\begin{abstract}
[IMPLEMENTASI PELATIHAN E-LEARNING DI ERA PADEMIC]. With the COVID-19 pandemic, all activities in public and private offices have changed. This pandemic is not only happening in Indonesia but throughout the country. This pandemic requires everyone to keep a distance so as not to come into contact with people who can cause the Covid 19 virus to be contagious. Therefore, the Palembang diversity training center also adjusted its training system from conventional to being changed to e-learning training. This research on the implementation of elearning training aims to determine how the implementation of elerning training in the Palembang diversity training center and also to find out what are the inhibiting and supporting factors of e-learning training. The research method used is descriptive qualitative method. And the results obtained by the Palembang religious education and training center have carried out e-learning training with the following stages: planning, organizing, implementing and evaluating e-learning training. For inhibiting factors, there are three factors, namely training participants' knowledge of IT, internet networks and motivation and commitment of training participants. While the supporting factors are the preparation made by the Palembang religious education and training center for the committee with their widyaiswaranya for the implementation of berbasis e-learning training, the availability of a Wifi network at the Palembang religious training center, the existence of quota replacement money for training participants, widyaiswara and committees as well as the times that support the implementation of berbasis e-learning training. From the results of the study, it can be concluded that the Palembang diversity education and training center has carried.
\end{abstract}

Keywords: training, e-learning 


\section{PENDAHULUAN}

Aparatur Negeri Sipil (ASN) Kementerian Agama bekerja membantu pemerintah dalam bidang keagamaan. Adapun tugas pokok kementerian agama yang akan dilaksanakan oleh ASN adalah menyelenggarakan urusan di bidang keagamaan dalam pemerintahan untuk membantu Presiden dalam menyelenggarakan pemerintahan negara. Oleh karena itu perlu Sumber Daya Manusia (SDM) ASN yang unggul dan mampu dalam melaksanakan tugas pokoknya. Pemerintah memiliki kewajiban dalam meningkatkan mutu ASN. Pada kementerian Agama Lembaga yang bertugas meningkatkan SDM ASN Kementerian Agama adalah Badan Penelitian dan Pengembangan, dan Pendidikan dan Pelatihan Kementerian Agama. Untuk mewujudkan SDM Kementerian Agama yang berkualitas, profesional, berintegritas dan bertanggung jawab, perlu diselenggarakan pendidikan dan pelatihan pegawai yang dilaksanakan oleh Pusat Pendidikan dan Pelatihan Tenaga Administrasi dan Pusat Pendidikan dan Tenaga Teknis Pendidikan dan Keagamaan yang selanjutnya disebut Pusdiklat Tenaga Administrasi dan Pusdiklat Tenaga Teknis Pendidikan dan Keagamaan (Peraturan Menteri Agama, 2020). Salah satunya adalah Balai Diklat Keagamaan (BDK) Palembang. BDK Palembang merupakan salah satu dari 14 BDK yang ada di negara Republik Indonesia seperti yang terdapat dalam PMA NO 10 (Peraturan Menteri Agama, 2018). Dengan wilayah kerja BDK Palembang meliputi propinsi Sumatera Selatan, Bengkulu, Lampung dan Kepulauan Bangka Belitung.

Semenjak Pandemi COVID-19 berdampak pada berbagai aspek kehidupan manusia. Tidak hanya berdampak pada aktivitas usaha, Pandemi COVID-19 nyatanya berdampak pula pada model pengembangan kompetensi ASN khususnya jalur diklat atau pelatihan. Pengembangan kompetensi ASN adalah upaya untuk pemenuhan kebutuhan kompetensi ASN dengan standar kompetensi jabatan dan rencana pengembangan karir(Peraturan Kepala Lembaga Administrasi Negara, 2018). Sekarang pelatihan berbasis e-learning menjadi pilihan di masa-masa sulit ini. Dimana pada tahun-tahun sebelumnya pelatihan berbasis e-learning sebenarnya sudah dilakukan oleh lembaga-lembaga pelatihan baik lembaga pelatihan milik pemerintah maupun swasta. Namun pelatihan berbasis e-learning semacam itu belum familiar di kalangan ASN. Karena dahulu pelatihan yang sifatnya konvensional atau tatap muka langsung di kelas lebih sering dilaksanakan daripada pelatihan berbasis e-learning. Berhubung adanya Pandemik COVID-19 maka pelatihan dilaksanakan secara berbasis $e$ learning. Pelatihan secara berbasis $e$ learning ini memberikan dampak positif hingga dampak negatif. Pelatihan secara berbasis e-learning ini pengajar (widyaiswara) dituntut untuk mempersiapkan pembelajaran sebaik dan sekreatif mungkin dalam menyampaikan suatu mata pelatihan. Dalam proses pelatihan secara berbasis e-learning bukan saja melibatkan pengajar peserta pelatihan 
juga sangat menentukan keberhasilan dalam pelaksanaan pelatihan berbasis $e$ learning. Apabila tenaga pengajar, peserta pelatihan dan panitia kurang memahami tentang internet maka proses pelatihan berbasis e-learning akan mengalami kendala. Begitu juga dengan jaringan internet juga memberikan andil yang cukup besar keberhasilan pelatihan berbasis $e$ learning.

Pelatihan berbasis e-learning sangat bergantung kepada jaringan internet yang ada baik itu pengajar maupun peserta pelatihan. Sebagai contoh peserta yang berada di daerah yang kebetulan jaringan internetnya bermasalah akhirnya menjadi frustasi karena tidak bisa menyambungkan internet sehingga tidak mengikuti pelatihan secara maksimal begitu pula dengan pengajar persiapan mengajar sudah maksimal pada saat menyampaikan materi tiba-tiba internet putus sehingga apa yang disampaikan tidak bisa sampai kepada peserta pelatihan. Hal ini memberikan gambaran bahwa apabila jaringan internet yang lemah juga menjadi salah satu faktor yang dapat menghambat proses pembelajaran (pelatihan) berbasis $e$ learning. Oleh karena itu kualitas jaringan internet yang tersebar harus lancar dan stabil. Disamping itu pengajar juga kesulitan dalam menyampaikan materi pelatihan dikarenakan tidak semua peserta pelatihan berantusias dalam mengikuti proses pembelajaran berbasis e-learning.

Dari hasil wawancara penulis dengan beberapa tim pengajar pada pelatihan berbasis e-learning dapat disimpulkan bahwa faktor yang mempengaruhi pelatihan berbasis e-learning ini adalah kekuatan jaringan internet serta faktor pendukungnya yaitu handphone yang memiliki fitur canggih, komputer atau laptop. Jaringan internet yang sering putusputus membuat proses pembelajaran pada pelatihan berbasis e-learning tidak berjalan secara maksimal. Sehingga beberapa peserta pelatihan mengalami beberapa kesulitan dalam memahami materi pelajaran yang diberikan. Begitu pula pengajar dengan bermasalahnya jaringan internet maka kesulitan dalam mengukur sejauh mana peserta pelatihan paham dengan materi yang disampaikan.

Beradasarkan penjelasan diatas maka penulis ingin meneliti bagaimana implementasi Pelatihan era Pandemik. Penelitian ini dilaksanakan untuk mengetahui implemtasi pelatihan berbasis e-learning di era Pandemik dikarenakan pelatihan secara berbasis e-learning ini belum begitu familiar didunia pelatihan. Pelatihan berbasis e-learning ini baru dilaksanakan setelah bangsa Indonesia maupun dunia mengalami Pandemik covid19. Dimana tujuan pelatihan berbasis $e$ learning adalah meningkatkan kualitas SDM ASN kementerian Agama pada masa Pandemik COVID-19.

\section{Identifikasi Masalah}

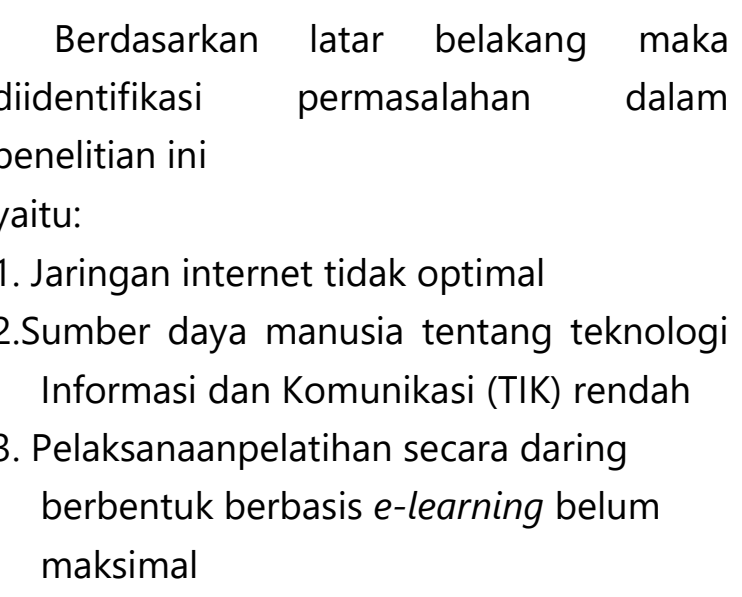




\section{Perumusan Masalah}

Adapun identifikasi dalam penelitian ini adalah sebagai berikut:

1. Bagaimana implementasi pelatihan berbasis berbasis e-learning di era Pandemik

2. Apa saja faktor yang menjadi penghambat implementasi pelatihan berbasis e-learning era Pandemik

3. Apa saja faktor pendukung implementasi pelatihan berbasis berbasis e-learning di era Pandemik

\section{Tujuan Penelitian}

Tujuan penelitian ini untuk mengetahui: implementasi pelatihan berbasis e-learning di era pandemic, faktor-faktor penghambat dan pendukungnya

\section{METODE PENELITIAN}

Jenis penelitian yang digunakan adalah penelitian kualitatif. Dengan sumber datanya ada dua jenis sumber data primer yaitu kepala dan widyaiswara balai diklat keagamaan Palembang dan sumber data sekunder yaitu dokumentasi seperti laporan pelaksanaan pelatihan dan juga rekaman video pelaksanaan pelatihan berbasis $e$ learning. Dengan prosedur pengumpulan data yang digunakan yaitu 1) observasi terhadap pelaksanaan pelatihan berbasis $e$ learning melalui rekaman video pelatihan berbasis e-learning; 2) wawancara terhadap kepala balai dan juga widyaiswara yang terlibat dalam pelaksanaan pelatihan berbasis e-learning; 3) Dokumentasi yang bertujuan untuk data pendukung dan pelengkap bagi data primer yang didapatkan dari observasi dan wawancara.

\section{TEMUAN DAN PEMBAHASAN}

\section{Temuan}

Hasil penelitian implementasi pelatihan jarak jauh daring adalah sebagai berikut

\section{Balai Diklat Keagaman Palembang}

Balai Diklat Keagamaan Palembang merupakan satuan kerja institusi kediklatan di bawah Badan Litbang dan Diklat Kementerian Agama Republik Indonesia yang bertugas melayani pegawai (ASN) Kementerian Agama dengan wilayah kerja adalah provinsi Sumatera Selatan, Lampung, Bengkulu dan Kepulauan Bangka Belitung(Peraturan Menteri Agama, 2018). Nomenklatur Balai Diklat Keagamaan Palembang menurut PMA No. 10 Tahun 2018 terdiri dari eselon III (Kepala Balai), eselon IV (Kasubag TU, Seksi Diklat Tenaga Teknis Pendidikan dan Keagamaan, dan Seksi Diklat Tenaga Administrasi), serta kelompok jabatan fungsional (widyaiswara, arsiparis, pustakawan, perencana dan analis kepegawaian).

Jumlah pegawai BDK Palembang 66 Orang ditambah 10 orang tenaga honorer yang melayani 21.000.000 ASN tersebar dalam berbagai jabatan struktural dan fungsional menempati tugas di Kanwil, Perguruan Tinggi Keagamaan, Kemenag Kab/Kota, sekolah/madrasah dan KUA kecamatan. Pada empat wilayah propinsi Sumatera Selatan, Lampung, Bengkulu dan Kep. Bangka Belitung (https://simlitbangdiklat.kemenag.go.id/).

Balai diklat keagaman Palembang memiliki visi dan misi. Visi balai diklat Keagamaan Palembang: Terwujudnya Balai Diklat Keagamaan Palembang yang 
Profesional, Disiplin dan Berintegritas Tinggi.

Misi Balai Diklat Keagamaan Palembang:

1) Penguatan Kapasitas Kelembagaan Untuk mampu menjadi lembaga diklat yang profesional, maka penguatan kapasitas internal (internal capacity building) perlu terus ditingkatkan, baik yang menyangkut sarana dan prasarana, SDM penyelenggara diklat, widyaiswara, anggaran, proses organisasi hingga manajemen pengelolaan lembaga diklat. Karena itu penguatan kapasitas kelembagaan perlu dilakukan secara sistematis dan berkesinambungan agar nantinya mampu menjadi daya dukung bagi tercapainya tugas-tugas substansial organisasi.

2) Perluasan Akses dan Peningkatan Mutu Penyelenggaraan Diklat

Mengingat kebutuhan akan diklat-diklat yang terus berkembang maka perlu dilakukan kajian dan analisis dengan tepat terhadap perkembangan diklatdiklat sehingga dapat ditingkatkan baik secar kuantitas maupun kualitas termasuk kajian dan analisis yang tepat agar akses pegawai terhadap perkembangan diklat-diklat dapat terus ditingkatkan.

3) Pengendalian Mutu Penyelenggaraan Diklat

Untuk memastikan bahwa pengelolaan dan penyelenggaraan diklat sudah sesuai dengan standar kediklatan atau telah sesuai dengan berbagai regulasi kediklatan, perlu melakukan pengendalian mutu/akreditasi terhadap pengelolaan dan penyelenggaraan diklat sesuai mekanisme yang telah ditetapkan.

Tujuan yang hendak dicapai Balai Diklat Keagamaan Palembang dalam jangka waktu satu sampai dengan lima tahun, dan tujuan mengacu kepada pernyataan visi dan misi. Adapun tujuan yang hendak dicapai Balai Diklat Keagamaan Palembang adalah terselenggaranya diklat baik diklat di bidang Tenaga Administrasi maupun Tenaga Teknis Pendidikan dan Keagamaan yang berkualitas sehingga mampu mewujudkan diklat yang berkualitas, berkarakter dan berakhlak mulia, antara lain

1) Menyiapkan Sumber Daya Aparatur Kementerian Agama melalui penyelenggaraan diklat Tenaga Administrasi yang meliputi bidang diklat Prajabatan dan bidang diklat dalam jabatan. Pendidikan dan Pelatihan Prajabatan untuk Aparatur Sipil Negera (ASN) terdiri dari Pelatihan Dasar (Latsar) Gol. I, Pelatihan Dasar (Latsar) Gol. II, Pelatihan Dasar (Latsar) Gol. III. Pendidikan dan Pelatihan Dalam Jabatan terdiri dari Pelatihan Fungsional Administrasi, Pelatihan Teknis Administrasi dan Pelatihan Kepemimpinan Pengawas (PKP).

2) Menyiapkan Sumber Daya Aparatur Kementerian Agama melalui penyelenggaraan diklat Tenaga Teknis Pendidikan dan Keagamaan yang meliputi bidang Teknis Fungsional dan bidang diklat Teknis Substantif. Diklat Teknis Fungsional terdiri dari diklat Teknis Fungsional Pembentukan Jabatan Tenaga Teknis Pendidikan, diklat Teknis Fungsional Pembentukan Jabatan 
Tenaga Teknis Keagamaan, diklat Teknis

Fungsional Peningkatan Kompetensi

Tenaga Teknis pendidikan dan diklat

Teknis Fungsional Peningkatan

Kompetensi Tenaga Teknis Keagamaan.

Diklat Teknis Substantif terdiri dari diklat

Substantif Pembekalan Tugas Tambahan
Tenaga Teknis Pendidikan, diklat Substantif pembekalan Tugas Tambahan Tenaga Teknis keagamaan, diklat Substantif Peningkatan Kompetensi Tenaga Teknis pendidikan dan diklat Substantif Peningkatan Kompetensi Tenaga Teknis Keagamaan.

\section{Implementasi Pelatihan Berbasis E-learning}

Reduksi Hasil Wawancara Peneliti di Balai Diklat Keagamaan Palembang

\begin{tabular}{|l|l|}
\hline \multicolumn{1}{|c|}{ Indikator } & \multicolumn{1}{c|}{ RINGKASAN HASIL WAWANCARA } \\
\hline Sistem belajar e- & $\begin{array}{l}\text { Semenjak Pandemik berlangsung maka pelatihan dialihkan dari bentuk } \\
\text { leanvensional menjadi pelatihan berbasis e-learning }\end{array}$ \\
\hline Perencanaan & $\begin{array}{l}\text { Perencanaan pelatihan berbasis e-learning pada Balai Diklat Keagamaan } \\
\text { Palembang diawali dengan sosialisasi tentang perencanaan kepada } \\
\text { seluruh pegawai Balai Diklat Keagamaan Palembang kemudian Balai } \\
\text { Diklat Keagamaan Palembang mengadakan bimbingan teknis tentang } \\
\text { pemanfaatan Teknologi Informasi dan Komunikasi (TIK) bagi panitia dan } \\
\text { widyaiswara. Kemudian Balai Diklat baru mengkoordinasikan dengan } \\
\text { kanwil kemenag diwilayah kerja Balai Diklat Keagamaan Palembang. }\end{array}$ \\
\hline Pengorganisasian & $\begin{array}{l}\text { Setiap pelaksanaan pelatihan baik secara konvensional maupun } \\
\text { berbasis e-learning balai diklat membentuk panitia yang bertugas } \\
\text { menjamin kelancaran pelaksanaan pelatihan dan juga penunjukan } \\
\text { tenaga pengajar (widyaiswara) serta meminta peserta kepada stake } \\
\text { holder yaitu kanwil diwilayah kerja Balai Diklat Keagamaan Palembang }\end{array}$ \\
\hline Pelaksanaan & $\begin{array}{l}\text { Pelatihan berbasis e-learning menggunakan kurikulum yang sama } \\
\text { dengan pelatihan konvensional namun karena dalam aturan LAN } \\
\text { bahawa pembelajaran secara berbasis e-learning hanya 3 jam satu hari } \\
\text { maka jumlah tatap mukanya dikurangi menjadi hanya sekitar 2-3 jam } \\
\text { saja }\end{array}$ \\
\hline Faktor Pendukung & $\begin{array}{l}\text { Evaluasi pada pelatihan berbasis e-learning terdiri dari evaluasi } \\
\text { terhadap proses pembelajaran dilakukan oleh widyaiswara, panitia dan } \\
\text { peserta pelatihan dan juga evaluasi terhadap sarana prasarana } \\
\text { dilakukan oleh peserta pelatihan dan widyaiswara serta evaluasi } \\
\text { terhadap kepanitian yang dilakukan oleh peserta pelatihan }\end{array}$ \\
\hline $\begin{array}{l}\text { Dalam pelaksanaan pelatihan berbasis elearning maka faktor } \\
\text { pendukung untuk mencapai kesuksesan dari pelatihan ini antara lain } \\
\text { a. adanya persiapan yang dilakukan Balai Diklat Keagamaan Palembang } \\
\text { terhadap panitia dengan widyaiswaranya terhadap pelaksanaan } \\
\text { pelatihan berbasis e-learning } \\
\text { b. Tersedianya jaringan Wifi Dibalai Diklat Keagamaan Palembang } \\
\text { c. Adanya uang penggantian kuota untuk peserta pelatihan, } \\
\text { widyaiswara dan panitia }\end{array}$ \\
\hline
\end{tabular}




\begin{tabular}{|l|l|}
\hline \multirow{5}{*}{ Faktor Penghambat } & $\begin{array}{l}\text { d. Perkembangan zaman yang mendukung pelaksanaan pelatihan } \\
\text { berbasis e-learning }\end{array}$ \\
& $\begin{array}{l}\text { Dalam pelaksanaan pelatihan berbasis e-learning masih terdapat hal- } \\
\text { hal yang menghambat pencapaian tujuan pelatihan yang telah } \\
\text { ditentukan }\end{array}$ \\
& $\begin{array}{l}\text { a.Belum adanya sosialisasi balai diklat keagamaan Palembang tentang } \\
\text { pelatihan berbasis elearning kepada stakeholder diwiliyah kerja Balai } \\
\text { Diklat Keagamaan Palembang } \\
\\
\text { b. Kondisi jaringan internet pada peserta pelatihan sering bermasalah } \\
\text { c. Kondisi alam yang sering mati lampu, hujan badai dan sebagainya }\end{array}$ \\
\hline
\end{tabular}

\section{Pembahasan}

\section{Implementasi Pelatihan E-learning Era Pandemik}

Pelatihan pada kementeriana agama dilaksanakan secara klasikal dan non klasikal (Peraturan Menteri Agama, 2020). Pelatihan yang dilaksanakan pada masa Pandemik salah satunya bentuk non klasikal e-learning. E-learning merupakan Peningkatan Kompetensi yang dilaksanakan dalam bentuk pelatihan dengan penggunaan TIK secara optimal untuk mencapai tujuan pelatihan dan peningkatan kinerja PNS (Peraturan Kepala Lembaga Administrasi Negara, 2018)

Berdasarkan hasil wawancara penulis dengan kepala balai diklat keagamaan Palembang dan karyawannya dapat disimpulkan bahwa pada masa Pandemik Balai Diklat Keagamaan Palembang untuk di kantor sendiri melaksanakan pelatihan dalam bentuk e-learning. Hal ini sesuai dengan ketentuan protokol kesehatan. Sehingga tugas pokok Balai Diklat Keagamaan Palembang dapat berjalan sesuai dengan yang direncanakan diawal tahun.

Pelatihan secara e-lerning ini sebenarnya bagi Balai Diklat Keagamaan Palembang telah diterapkan beberapa tahun yang lewat cuma belum seinten sekarang ini. Kemaren hanya untuk mengikuti perkembangan zaman dan juga untuk meningkatkan pemerataan ASN kementerian agama dalam mengikuti pelatihan.

Tapi semenjak Pandemik COVID 19 ini mau tidak mau siap tidak siap harus melaksanakan pelatihan berbentuk $e$ learning. Begitu pula dengan Balai Diklat Keagamaan Palembang untuk pelaksanaan pelatihan e-learning ini kepala Balai Diklat Keagamaan Palembang sudah mulai menyiapkan karyawan balai untuk menyiapkan diri dalam pelaksanaan pelatihan e-learning dengan mengadakan bimbingan teknis tentang penggunaan internet untuk pelatihan e-learning seperti penggunaan aplikasi Google Classroom dalam pelatihan e-learning. Dan dilihat dari motivasi pegawai terbilang cukup baik. Mereka mengikuti bimbingan teknis ini dari awal pelaksanaan sampai berakhirnya sesi bimbingan. Bahkan diluar jam bimbingan teknis para pegawai di Balai Diklat Keagamaan Palembang masih lanjut berdiskusi tentang Gloogle Classroom dan bahkan ditambah lagi dengan mendiskusikan penggunaan aplikasi Zoom karena nantinya akan digunakan dalam proses pelatihan e-learning khususnya sesi tatap 
muka. Tapi karna jumlah jam pelatihan oleh Lembaga Administrasi Negara (LAN) menjadi 3 JP sehari (Peraturan Kepala Lembaga Administrasi Negara, 2018b) maka proses tatap muka pada pelatihan e-learning ini hanya paling lama 3 jam.

Pelaksanaan pelatihan e-learning di balai diklat keagamaan Palembang berdasarkan panduan yang dikeluarkan oleh pusdiklat tenaga teknis. Dimana pembelajaran secara elearning memiliki empat tahapan yaitu perencanana, pengorganisasian, pelaksanaan dan pengevaluasian (Wahyuningsih dan Makmur, 2017)

1) Perencanaan

Perencanaan merupakan upaya yang dilakukan untuk mengantisipasi apa yang terjadi dimasa akan datang berupa startegi dan taktik yang tepat untuk mewujudkan tujuan yang ditentukan. Dalam perencaan harus menjawab enam pertanyaan yaitu apa, dimana, bagaimana, bilamana, siapa dan mengapa (Tisnawati dan Saefullah, 2012). Dalam proses pembelajaran kita juga perlu Menyusun perencanaan pembelajaran agar saat pelaksanaan pembelajaran secara elearning dapat berjalan seoptimal mungkin. Sehingga tujuan yang ingin dicapai cepat terwujud.

Perencanaan pembelajaran $e$ learning artinya kita membuat persiapan apa saja yang akan kita siapkan untuk melaksanakan proses pelatihan secara e-learning. Bila kita berpijak pada pengertian perencanaan diatas maka dalam perencanaan pelatihan tersebut harus dapat menjawab hal-hal sebagai berikut: Apa yang akan dipersiapkan dalam hal ini balai diklat telah menyiapkan Sumber Daya Manusia untuk panitia dan juga widyaiswaranya dengan mengadakan bimbingan Teknis tentang penggunaan internet. Dimana akan dilaksanakan pelatihan elearning yaitu di Balai Diklat Keagamaan Palembang. Bagaimana pelaksanaan pelatihan e-learningnya dengan cara tatap muka langsung memanfaatkan aplikasi Zoom dan ditunjang dengan aplikasi Google Classroom. Bilamana pelaksanaan pelatihan e-learning waktunya sudah direncanakan sepuluh hari sebelum pelaksanaan pelatihan e-learning maka pihak balai diklat memberitahukan kepada widyaiswara, stakeholder dan juga pegawai balai yang akan menjadi panitia. Siapa yang terlibat dalam pelatihan e-learning ini terdiri dari peserta pelatihan adalah ASN kementerian agama yang berada di wilayah kerja Balai Diklat Keagamaan Palembang. Mengapa pelatihan e-learning ini dilakukan karena bangsa kita sedang mengalami musibah Pandemik COVID-19 sementara tugas pokok balai diklat adalah mengadakan pelatihan untuk meningkatkan kinerja ASN kementerian agama. Dan dari beberapa pertanyaan yang ada pada perencanaan maka dapat dikatakan Balai Diklat Keagamaan Palembang ini sudah melaksanakan kegiatan perencanaan sebelum pelaksanaan pelatihan berbasis e-learning. 
Sementara itu perencanaan yang harus dilaksanakan sebelum pelatihan berbasis e-learning adalah:

a. Administrasi terhadap data staf edukasi, karyawan, kurikulum, mata pelajaran dan data peserta didik (pelatihan)

b. Mempersiapkan proses pembelajaran melalui upload dan download materi pelajaran, proses pemeliharaannya, tugas akhir dan ujian

c. Membentuk pembelajaran meliputi penyusunan materi pembelajaran yang menarik, menciptakan suasana belajar yang kondusif

d.. Membuat kemudahan akses bagi guru dan siswa terhadap internet, wifi dan laboratorium

e. Membuat semua guru dan siswa dapat mengakses dan memanfaatkan LMS dengan mudah.

f. Menyediakan panduan tata cara melaksanakan pembelajaran elearning untuk guru dan siswa (Wahyuningsih dan Makmur, 2017)

Balai diklat keagamaan Palembang sebelum melaksanakan pelatihan secara berbasis e-learning terlebih dahulu melaksanakan perencanaan. Hal ini dapat dilihat dari hasil wawancara sebagai berikut:

"Perencanaan pelatihan e-learning telah dilakukan jauh hari sebelum pelaksanaan pelatihan diawali dengan sosialisasi yang dilakukan oleh kepala balai diklat keagamaan tentang pelatihan secara berbasis e-learning kemudian diikuti dengan mengadakan bimtek sehari tentang pemanfaatan internet untuk keperluan pelatihan yang diikuti oleh semua pegawai balai diklat keagamaan Palembang. Baru kemudian balai merencanaan pelaksanaan pelatihan berbasis e-learning dan langsung menginformasikan kepada satuan kerja dibawah wilayah kerja Balai Diklat Keagamaan Palembang. Sementara itu balai juga membentuk panitia dan tim pengajar yang berasal dari widyaiswara Balai Diklat Keagamaan Palembang. Kemudian baik panitia dan juga widyaiswara mulai menyiapkan sesuatu yang berhubungan dengan tugas masing-masing"

Dari hasil wawancara diatas maka penulis akan menguraikan apakah balai diklat keagamaan Palembang telah melaksanakan perencanaan pelatihan elearning sebagai berikut

a. Administrasi terhadap data staf edukasi, karyawan, kurikulum, mata pelajaran dan data peserta didik (pelatihan)

Pada kegiatan ini balai diklat terlebih dahulu mengirimkan surat pemberitahuan tentang akan diadakannya pelatihan e-learning sekaligus meminta admin dari masing-masing satuan kerja (satker) untuk mendaftarkan ASN yang sesuai dengan ketentuan yang telah ditetapkan. Kemudian 
balai diklat menentukan tenaga pengajar yang akan mengajar pada pelatihan e-learning yaitu berdasarkan spesialisasi widyaiswara apabila tidak terpenuhi maka Balai Diklat Keagamaan Palembang meminta bantuan kepada LPMP, UIN Raden Fatah Palembang, UNSRI dan sebagaianya. Dan juga Balai Diklat Keagamaan Palembang membentuk panitia pelatihan $e-$ learning yang terdiri dari pegawai dilingkungan Balai Diklat Keagamaan Palembang

b. Mempersiapkan proses pembelajaran melalui upload dan download materi pelajaran, proses pemeliharaannya, tugas akhir dan ujian Setelah panitia pelatihan terbentuk kemudian panitia menghubung widyaiswara untuk memberitahukan keikut sertaannya dalam pelatihan elearning dan meminta widyaiswara menyiapkan materi dan tugas yang akan di kerjakan oleh peserta pelatihan dan meminta menguploadnya ke Google Classroom yang sudah disiapkan paling lama satu hari sebelum pelaksanaan pelatihan $e$ learning. Dan panitia bidang akademis membuatkan jadwal untuk peserta pelatihan mendowload materi dan tugas yang sudah dibuat oleh widyaiswara.

c. Membentuk pembelajaran meliputi penyusunan materi pembelajaran yang menarik, menciptakan suasana belajar yang kondusif Untuk tahapan ini waidyaiswara telah menyiapkan Rancang Bangun Pembelajaran Mata Diklat (RBPMD) dan juga Rencana Pembelajaran (RP) sama seperti untuk pelatihan klasikal. Hal ini disebabkan karena banyaknya widyaiswara yang belum begitu paham dalam memanfaatkan teknologi informasi dalam proses pembelajaran sehingga mereka hanya menyiapkan bahan tayang berupa powerpoint yang sering digunakan pada pelatihan konvensional. Ditambah lagi widyaiswara juga harus mempelajari juga bagaimana menggunakan beberapa aplikasi seperti Zoom dan Google Classroom dalam jangka waktu 10 hari.

d. Membuat kemudahan akses bagi guru dan siswa terhadap internet, wifi dan laboratorium Balai diklat keagamaan Palembang telah menyediakan jaringan internet berupa wifi yaitu berada pada kantor utama balai diklat dan juga diruang kelas yang ada dibalai juga di ruangan widyaiswara sendiri. Sehingga akan memberikan kemudahan dalam melaksanakan tugasnya baik itu panitia dan juga widyaiswara. Disamping itu balai diklat keagaman Palembang juga menyediakan uang penggantian kuota untuk peserta pelatihan, widyaiswara dan juga panitia sesuai dengan ketentuan yang berlaku. 
e. Membuat semua guru dan siswa dapat mengakses dan memanfaatkan Learning Management System (LMS) dengan mudah

Untuk LMS saat ini balai diklat keagamaan Palembang belum tersedia dan untuk mencapai kelancaran dalam pelatihan $e$ learning maka balai diklat memanfaatkan aplikasi Google Classroom sebagai penggantinya. Pada Google Classroom inilah widyaiswara memasukan materi dan juga tugas untuk peserta pelatihan. Dan Google Classroom inilah tempat peserta pelatihan mengirimkan tugas mereka. Satu hari sebelum pelatihan dimulai maka panitia mensosialisasikan bagaiman mengoperasikan Google Classroom ini kepada peserta pelatihan.

f. Menyediakan panduan tata cara melaksanakan pembelajaran elearning untuk guru dan siswa

Bedasarkan wawancara penulis dengan panitia pelatihan didapatkan informasi bahwa pada pelatihan secara e-learning ini Balai Diklat Keagamaan Palembang belum menyusun panduan pelaksanaan pelatihan e-learning untuk peserta pelatihan dan juga untuk widyaiswara. Untuk mempermudah pelaksanaan pelatihan secara e-learning ini maka panitia memberikan penjelasan saja sekilas cara menggikuti pelatihan secara $e$ - learning ini dan mereka terbuka untuk dihubungi apabila dalam pelaksanaan pelatihan terjadi kendala.

Disamping merencanakan untuk proses pembelajarannya maka perlu juga mempersiapkan komponen perencanaan pelatihan e-learning. Berikut ini diuraikan komponenkomponen perencanan sistem pelatihan berbasis e-learning:

\section{a. Hardware}

Hadware atau perangkat keras yang terdapat pada sistem belajar e-learning meliputi input/output device, memory, modem/wifi, pengolahan (processor) dan perihal lainnya (Wahyuningsih dan Makmur, 2017)

Dari hasil observasi pada balai diklat didapatkan bahwa balai diklat keagamaan Palembang telah memiliki, jaringan Wifi, modem, laptop yang dapat digunakan untuk kelancaran pelaksanaan pelatihan berbasis e-learning. Dan dari hasil wawancara dengan peserta pelatihan pada umumnya telah memiliki laptop dan juga android serta di madrasah tempat peserta pelatihan juga memiliki wifi, dan juga laptop.

Berdasarkan hasil observasi dan wawancara maka dapat diketahui bahwa

untuk unsur hardware pelaksanaan pelatihan berbasis $e$ learning pada Balai Diklat Keagamaan Palembang sudah cukup baik dimana setiap panitia 
maupun widyaiswaranya sudah dilengkapi masing-masing dengan sebuah laptop dan ditambah pula adanya jaringan internet yang lancar karna masing-masing ruangan sudah dipasang hotspot berupa wifi sehingga mulai dari perencanaan, pelaksanaan dan pengevaluasi pelatihan berbasis $e$ learning dapat dilaksanakan dengan memanfaatkan internet. Dengan demikian akan sangat membantu dalam mencapai tujuan pembelajaran dengan pelatihan berbasis e-learning.

b. Komponen Perangkat Lunak (Software) Software merupakan perangkat lunak dalam sistem ini berupa program-program computer yang meliputi sistem operasi (operating system/OS), Bahasa program (programming language), dan program aplikasi (application).

Untuk perangkat lunak yang digunakan dalam pelatihan berbasis e-learning di balai diklat keagaman Palembang berupa aplikasi Google Classroom yang sudah ada. Google Classroom ini merupakan rumah tempat memasukan atau input data khususnya materi pelatihan dan juga tugas peserta pelatihan sedangkan data pada panitia masih menggunakan aplikasi khusus tentang pelatihan yaitu simdiklat.

c. Sumber Daya Manusia

Sumber daya manusia yang ada pada pelatihan berbasis e-learning ini antara lain operator, programmer, system analyst, pimpinan serta individu lain yang terlibat didalamnya.

Sumber daya manusia yang ada pada pelatihan berbasis e-learning dibalai diklat keagamana Palembang berdasarkan wawancara adalah kepala balai, widyaiswara, panitia dan peserta pelatihan.

Dari hasil observasi peneliti melihat bahwa yang mengelola pembelajaran langsung ditangani oleh tim pengajar yaitu widyaiswara yang juga dibantu oleh panitia juga.

Berdasarkan hasil observasi dan juga wawancara maka dapat disimpulkan bahwa sumber daya manusia yang ada pada pelatihan berbasis e-learning dibalai diklat keagamaan Palembang adlah kepala balai diklat, widyaiswara dan juga panitia pelatihan.

d. Database

Database berupa berkas yang terdiri dari sekumpulan data yang tersimpan dengan cara-cara tertentu sehingga dapat digunakan Kembali dengan mudah dan cepat membentuk suatu berkas.

Database dari pelatihan berbasis e-learning balai diklat keagamaan Palembang tersimpan dalam aplikasi khusus diklat yaitu simdiklat.

Perencanaan pelatihan sudah dilaksanakan dengan cukup baik oleh Balai Diklat Keagamaan Palembang 
sehingga pelaksanaan pelatihan $e$ learning dapat dilaksanakan dengan semaksimal mungkin.

2) Pengorganisasian

Pengorganisasian merupakan cara yang menyangkut bagaimana strategi dan taktik yang telah dirumuskan dalam perencanaan di rancang dalam bentuk struktur organisasi yang tepat dan tangguh, mendistribusikan sumber daya, merumuskan dan menetapkan struktur organisasi yang menunjukkan adanya garis kewenangan dan tanggung jawab, kegiatan perekrutan, penyeleksian pelatihan dan pengembangan SDM atau tenaga kerja, kegiatan penempatan SDM pada posisi yang paling tepat (Tisnawati dan Kurniawan, 2012). Pengorganisasian pelatihan berbasis e-learning ini bertujuan untuk membuat proses pelatihan elearning nyaman,menyenangkan dan memotivasi peserta pelatihan agar dapat dengan mudah menerima materi yang diberikan.

Berdasarkan hasil observasi pada balai diklat keagamaan Palembang bahwa struktur organisasi balai diklat terdiri dari kepala balai diklat, kasubbag Tata Usaha, Kasi tenaga teknis Pendidikan dan keagaman dan kasi administari serta kelompok jabatan fungsional tertentu yang terdiri dari jabatan widyaiswara, perencanaan, pranata computer, pustakawan, arsiparis dan sebagainya.

3. Pelaksanaan

Pelaksanaan merupakan cara menerapkan program agar bisa dijalankan oleh seluruh pihak dalam organisasi serta proses memotivasi agar semua pihak tersebut dapat menjalankan tugas dan tanggung jawabnya dengan penuh kesadaran dan produktivitas yang tinggi (Tisnawati dan Kurniawan, 2012).

Pelaksanaan pelatihan e-learning terdiri dari dua tahapan

a. Penyaluran materi pelatihan dengan cara mengunggah materi pelatihan ke dalam laman resmi Lembaga penyelnggaran pelatihan

b. Proses pembelajaran dari tahap pendahuluan, inti dan penutup dilaksanakan dalam sistem layanan pembelajaran secara dalam jaringan.

Pelaksanaan pelatihan secara $e$ learning pada balai diklat keagaman Palembang dapat dilihat dari hasil wawancara dibawah ini

"Pelatihan secara berbasis elearning menggunakan kurikulum yang sama dengan pelatihan konvensional namun karena dalam aturan LAN bahawa pembelajaran secara berbasis e-learning hanya 3 jam satu hari maka jumlah tatap mukanya dikurangi menjadi hanya sekitar 2-3 jam saja. Adapun media yang digunakan adalah media internet dan juga aplikasi yang membantu dalam proses pelatihan berbasis e-learning antara lain Zoom untuk melaksanakan tatap muka secara langsung. Kemudian WAG digunakan untuk tempat menyampaikan informasi dan juga diskusi singkat sedangkan wadah 
untuk upload tugas dan materi dari widyaiswara menggunakan aplikasi yang sudah ada yaitu Google Classroom"

Dari hasil observasi pada video rekaman pelatihan secara berbasis $e^{-}$ learning maka terlihat widyaiswara menyampaikan materi para peserta pelatihan sambal mendengarkan. Selama proses pelatihan widyaiswara sekali-kali memberikan pertanyaan singkat kepada peserta pelatihan. Dan ada beberapa peserta pelatihan yang menjawabnya.

Berdasarkan hasil wawancara dan observasi maka dapat disimpulkan sebagai berikut:

a. Penyaluran materi pelatihan dengan cara mengunggah materi pelatihan ke dalam laman resmi Lembaga penyelnggaran pelatihan.

Untuk komponen ini widyaiswara sudah menyiapkan materi dan tugas yang akan dikerjakan peserta di Google Classroom dan panitia sudah menentukan jadwal peserta pelatihan untuk mendownload materi pelatihan. Materi tersebut akan dipelajari peserta pelatihan secara mandiri dan setalah selesai mempelajarinya peserta pelatihan melaksanakan tugas yang sudah diunduh ke Google Classroom.

Dari hasil wawancara dengan widyaiswara maka didapatkan informasi bahwa banyak peserta pelatihan yang tidak mengdownload materi diklat dan tugas sesuai dengan jadwal yang sudah ditentukan. Banyak alasan peserta pelatihan mengapa mereka tidak melakukan antara lain mereka tidak melihat jadwal sehingga tidak tahu bahwa ada kegiatan mengunduh materi pelatihan dan tugas. Karena kegiatan ini tidak ada pada pelatihan konvensional karena dalam mindsetnya pelatihan elearning sama saja dengan pelatihan konvensional Cuma tatap mukanya didepan laptop.

Pelatihan secara e-learning sangat berbeda sekali dengan pelatihan konvensional. Pada pelatihan e-learning jumlah jam tatap muka dalam satu hari hanya 3 jam dengan kurikulum yang sama dengan pelatihan konvensional. Sehingga untuk melengkapi jumlah jamnya maka pelatihan e-learning ini akan ada kegiatan belajar mandiri . Begitu pula tugas yang diberikan atau yang diunduh pada Google Classroom juga belum dikerjakan oleh peserta pelatihan dengan alasan belum paham tentang tugas tersebut karena widyaiswara belum menjelaskannya.

Artinya pada tahap belajar mandiri pada pelatihan ini belum berhasil karena banyak faktor yang menyebabkan antara lain mindset peserta pelatihan elearning bahwa pelatihan ini sama halnya dengan webinar yang sering dilakukan oleh 
masyarakat. Padahal yang Namanya pelatihan sangat berbeda dengan webinar,alasan jaringan yang ada pada wilayah peserta pelatihan sehingga terhambat dalam mendowload materi dan tugas, serta tidak melihat jadwal sehingga tidak tahu bahwa ada kegiatan download materi pelatihan dan terakhir alasan mereka adalah bahwa mereka kurang memahami materi pelatihan sebelum widyaiswara menyampaikan materi.

Sampai saat kegiatan tatap muka dengan aplikasi Zoom banyak peserta pelatihan yang belum mempelajari dan membaca materi pelatihan yang diunduh dalam Google Classroom. Sehingga widyaiswara melaksanakan tatap muka seperti pelaksanaan tatap muka pada pelatihan konvensional sehingga waktu penyampaian materi belum maksimal.

b. Proses pembelajaran dari tahap pendahuluan, inti dan penutup dilaksanakan dalam sistem layanan pembelajaran secara dalam jaringan

Pelaksanana pelatihan secara elearning tidak jauh berbeda dengan pelaksanaan pelatihan secara konvensional perbedaannya durasi tatap muka dan media yang digunakan saja yang berbeda untuk pelatihan secara konvensional tatap muka langsung dengan face to face dan durasi waktu tatap mukanya sesuai dengan jam dalam kurikulum. Untuk melihat proses pelaksanaan pelatihan secara elerning penulis telah melakukan observasi pada video pelaksanan pelatihan elearning.

Dari hasil observasi terlihat bahwa proses pelatihan $e$ learning tidak jauh berbeda dengan pelatihan konvensioanl yang terdiri dari kegiatan pendahuluan, inti dan penutup.

Kegiatan pendahuluan widyaiswara menyapa peserta pelatihan kemudian memberikan motivasi dan penyampaian tujuan pembelajaran. Pada kegiatan pendahuluan ini widyaiswara tidak memberikan lce breaking penyemangat peserta pelatihan.

Kegiatan inti widyaiswara menyampaikan materi pelatihan dengan metode ceramah, dan tanya jawab kadang kala sinyal putus sehingga proses penyampaian materi terhenti. Pada kegiatan ini pun widyaiswara tidak memberikan ice breaking.

Kegiatan penutup widyaiswara mengakhiri presentasi materi pelatihan dengan memberikan pertanyaan dalam bentuk tanya jawab dan kemudian widyaiswara mengingatkan Kembali bahwa peserta pelatihan untuk mengerjakan tugas dan memngumpulkannya satu hari sebelum berakhirnya pelatihan. 
Dari hasil wawancara dan observasi maka dapat dilihat bahwa proses pembelajaran pada pelatihan elearning ini tidak jauh berbeda dengan pelatihan konvensional dimana peserta mau mempelajari materi pelatihan apabila sudah bertatap muka langsung dengan widyaiswara. Sehingga dari durasi waktu sudah dapat dinyatakan tujuan pembelajaran sulit untuk dicapai.

Keberhasilan pelatihan berbasis e-learning ini juga sangat dipengaruhi tiga faktor Untuk faktor-faktor yang mempengaruhi hasil belajar seperti infrastruktur. Pada balai diklat keagamaan sudah cukup memiliki infrastruktur untuk melaksanaan pelatihan secara berbasis $e$ learning dan ini dibuktinya pelaksanaan pelatihan sesuai dengan waktu yang direncanakan. Kedua faktor yang berkaitan dengan isi dan informasi. Proses pelatihan secara berbasis $e$ learning materi yang disampaikan dengan kebutuhan peserta pelatihan maka mereka akan tetap semangat dan antisius mengikuti pelatihan secara berbasis e-learning hal ini disebabkan karena motivasi yang mereka dapatkan langsung dari dalam diri mereka sendiri. Faktor yang ketiga adalah faktor yang berhubungan dengan kesiapan diri. Faktor yang terakhir ini merupakan faktor yang memang

harus menjadi salah satu
perhatian widyaiswara dalam
menyampaikan materi. Selama
pelatihan widyaiswara harus tetap
menyapu pandangan ke seluruh
peserta pelatihan sehingga
widyaiswara dapat cepat
mengetahui bagaiman kesiapan
peserta apabila sudah mulai
memudar menjadi tugas
widyaiswara untuk
mengembalikan kesiapan diri
merek untuk menerima materi
selanjutnya.

4. Pengevaluasian

Pengevaluasian atau pengawasan merupakan suatu cara yang dilakukan untuk memastikan seluruh rangkaian kegiatan yang telah direncanakan, diorganisasikan dan di Implementasikan bisa berjalan sesuai dengan target yang diharapkan sekalipun berbagai perubahan yang terjadi dalam suatu organisasi (Tisnawati dan Kurniawan, 2012).

Tahapan evaluasi terhadap
pelatihan secara berbasis e-learning
pada Balai Diklat Keagamaan
Palembang dapat dilihat dari hasil
wawancara sebagai berikut:
"Evaluasi pada pelatihan berbasis
e-learning terdiri dari evaluasi
terhadap proses pembelajaran
dilakukan oleh widyaiswara, panitia
dan peserta pelatihan dan juga
evaluasi terhadap sarana prasarana
dilakukan oleh peserta pelatihan dan
widyaiswara serta evaluasi terhadap
kepanitian yang dilakukan oleh
peserta pelatihan"


Dari hasil wwancara dapat dilihat bahwa proses evaluasi telah dilaksanakan terhadap semua komponen yaitu:

a.Evaluasi Terhadap Proses

Pembelajaran

Evaluasi ini dilaksanakan oleh widyaiswara terhadap hasil belajar peserta pelatihan. Yang bertujuan untuk melihat bagaimana proses pembelajaran yang telah dilakukan apakah sudah membuat peserta pelatihan belajar. Hal ini juga diperkuat dengan hasil observasi yang dilakukan terhadap video rekaman pelatihan. Dan ternyata hasil observasi memperlihatkan bahwa peserta pelatihan masih tetap semangat mengikuti pelatihan secara berbasis $e$ learning karena hasil wawncara dengan peserta pelatihan mereka menyatakan bahwa dengan mengikuti pelatihan secara berbasis e-learning meraka mendapatkan ilmu juga sertifikat walaupun kadang-kadang mereka berjuang untuk melawan rasa kantuk dan lelah menghadapi laptop atau HP.

b. Evaluasi terhadap Widayiswara

Evaluasi peserta pelatihan terhadap widyaiswara dilakukan dengan cara mereka menjawab beberapa pertanyaan berhubungan dengan widyaiswara yang dilakukan secara berbasis $e$ learning. Evaluasi peserta pelatihan terhadap widyaiswara memiliki fungsi untuk melakukan refleksi terhadap proses pembelajaran yang telah dilaksanakan. Dan juga bermanfaat bagi widyaiswara untuk meningkatkan lagi kinerjanya

c. Evaluasi terhadap Panitia

Evaluasi ini dilaksanakan oleh peserta pelatihan terhadap panitia pelatihan yang bertujuan untuk meningkatkan kinerja panitia.

\section{Faktor Penghambat Pelatihan Berbasis}

\section{E-learning di Era Pandemik}

Dalam pelaksanaan pelatihan elearning di Balai Diklat Keagamaan Palembang terdapat tiga faktor penghambat yaitu: faktor pertama adalah ketidakmampuan dalam penggunaan teknologi Informasi dan komunikasi (TIK), faktor kedua masalah jaringan, faktor ketiga kurang focus dalam pelaksanaan pelatihan. Faktor-faktor inilah yang menyebabkan banyak peserta pelatihan yang kurang memahami bagaimana mengikuti pelatihan elearning

Faktor kelemahan peserta pelatihan yang merupakan seorang guru bisa dijadikan sebagai kekuatan guru diera revolusi ini. Sebagai contoh Pedagogical and Content Knowledge plus Personality (TPACK-P) yang merupakan sebuah framework atau konsep dapat digunakan oleh guru sebagai pemecah masalah pada keadaan yang dihadapi. Dengan mempelajari ilmu teknologi dan informasi akhirnya seorang guru menguasainya maka guru dapat menciptakan generasi unggul dan membekali peserta didik dengan pengetahuan dan keterampilan IT (informasi teknologi). 
Perkembangan zaman dan teknologi yang berubah maka guru juga harus merubah cara mengajarnya dengan yang ter up to date antara lain bland learning, full berbasis e-learning dengan menggunakan computer based learning (CBI) contohnya ruangguru.com atau gurusd.net dan lain-lainnya yang dilaksanakan secara berbasis e-learning (Mubarak, 2018)

Peserta pelatihan yang mengalami kesulitan dalam mengolerasikan teknologi informasi (internet) serta rendah motivasi menggunakan internet dapat diberikan Pendidikan dan pelatihan, sehingga dapat menunjang kualitas peserta didik yang akan memasuki dunia kerja. Bentuk pelatiahn yang dapat diberikan antara lain in-servis, model ini dapat diberikan secara berkelanjutan sehingga dapat meningkatkan motivasi dan kerja guru (Kamil, 2003). Motivasi mengikuti pelatihan e-learning bukan saja untuk mendapatkan sertifikat saja , tetapi memotivasi guru untuk menjadi guru (Irawadi, dan Yustikarini, 2019) yang professional. Dengan demikian guru dapat membuat dan mencetak generasi yang bermutu

Mempelajari TIK bagi guru dalam bentuk in-service dapat mendukung kinerja guru baik internal maupun eksternal. Faktor kinerja guru dalam bentuk internal adalah kecerdasan, keterampilan dan kecakapan, kemmapuan dan minat, motif, Kesehatan, cita-cita dan tujuan pekerjaan. Sedangkan kinerja guru dalam bentuk eksternal adalah lingkungan kerja, komunitas dan sarana serta prasarana (Kartini;2005).

Teknologi informasi dan komunikasi sangat mempengaruhi kompetensi dan kinerja guru (Destiana dan Soenarto, 2014). Jadi agar kinerja dan kompetensi guru meningkat maka guru harus mempelajari teknologi informasi dan komunikasi. Para tenaga kerja yang unggul dan memiliki daya saing tinggi diciptakan oleh guru yang memiliki kinerja dan kompetensi baik pula.

Untuk meningkatkan dan mengembangkan kompetensi guru maka guru harus mengikuti pelatihan secara kontinu baik dengan model pre-service education maupun in-service education (Kamil,2003; Laird, 1985). Guru yang mengikuti pelatihan elearning sudah melaksanakan model in-service education. Model ini adalah fase meningkatkan kompetensi guru oleh Balai Diklat Keagamaan Palembang untuk meningkatkan dan mengembangkan kompetensi guru baik pendagogik, professional, kepribadian sosial.

Sedangkan model pre-service education didapatkan guru saat mengikuti PPG yang dilaksankan oleh Lembaga Pendidikan tenaga kependidikan (LPTK) untuk memperoleh kometensi pengetahuan, keterampilan dan sikap yang diperlukan saat melaksakan tupoksi sebagai guru. Setalah guru mengikuti pelatihan maka kompetnsi guru akan meningkat sehingga guru mampu merencanakan, melaksanakan, dan mengevaluasi hasil pembelajaran dengan baik. Dengan demikian maka kompetensi peserta didik 
akan meningkat. Untuk memenuhi jabatan dan self-actualization maka guru butuh dua jenis pelatihan tersebut (Kamil, 2003)

Contoh lain dari model in-service adalah program sertifikasi guru dan dosen merupakan usaha pemerintah dalam meningkatkan profesionalitas guru seperti tertuang dalam dalam UU no 14 Tahun 2005.

Pemberian sertifikasi untuk guru adalah sebagai bukti formal pemberian pengakuan guru sebagai tenaga profesional yang melekat tunjangan untuk meningkatkan kesejahteraan guru dan memberikan dampak pada peningkatan kualitas Pendidikan di Indonesia. Guru profesioanl adalah guur yang dapat mengelola pembelajaran dengan lebih baik karena memiliki perencanaan, pelaksanaan, evaluasi pembelajaran dan memiliki komitmen kerja.

Syarat guru secara administrasi dinyatakan sebagai guru professional salah satunya memiliki sertifikat guru, sebagaimana dalam UU no 14 tahun 2005 adalah guru yang memiliki kualifikasi akademik, kompetensi, sertifikasi pendidik, sehat jasmani dan rohani, serta memiliki kemampuan untuk mewujudkan tujuan Pendidikan nasional.

\section{Faktor Pendukung Pelatihan Berbasis Berbasis e-learning di Era Pandemik}

Keberhasilan dalam pelatihan secara berbasis e-learning sangat tergantung faktor-faktor yang dijadikan tolok ukur keberhasilan penerapan suatu sistem menurut London yang dikutip dalam buku Dian Wahyuningsih yaitu :

1. Tingginya tingkat penggunaan pelatihan secara berbasis e-learning

2. Sistem dapat membuat pengguna menjadi puas

3. Memiliki sikap yang menguntungkan para pengguna terhadap sistem informasi

4. Tujuan yang akan dicapai dan hubungan timbal balik keuangan untuk oragnisasi (Wahyuningsih dan Makmur, 2017)

Pada pelatihan secara berbasis $e$ learning terdapat juga faktor pendukung keberhasilan dalam pembelajaran secara berbasis e-learning. Hal ini dapat dilihat dari hasil wawancara

"Adanya persiapan yang dilakukan Balai Diklat Keagamaan Palembang terhadap panitia dengan widyaiswaranya terhadap pelaksanaan pelatihan berbasis e-learning, tersedianya jaringan Wifi Dibalai Diklat Keagamaan Palembang, adanya uang penggantian kuota untuk peserta pelatihan, widyaiswara dan panitia serta perkembangan zaman yang mendukung pelaksanaan pelatihan berbasis e-learning"

Dari hasil wawancara terlihat dalam pada pelatihan secara berbasis e-learning memiliki beberapa faktor yang menyebabkan proses pelatihan dapat berjalan sebagaiman mestinya.

Dan apabila dianalisa berdasarkan faktor-faktor yang menjadi tolok ukur keberhasil maka dapat dikelompokkan

1. Tingginya tingkat penggunaan secara berbasis e-learning adalah 
perkembangan zaman yang mendukung pelaksanaan pelatihan berbasis e-learning. Dengan adanya perkembangan zaman yang mengarah penggunaan IT dalam kehidupan sehari-hari maka penggunaan IT dalam kehidupan sehari-hari cukup tinggi malah sekarang anak bayi pun sudah mampu mengoperasikan IT seperti Handphone. Artinya dengan perkembangan zaman maka peserta pelatihan akan semakin mudah menggunakan IT sehingga akan meningkatkan motivasi untuk belajar.

2. Sistem dapat membuat peserta menjadi puas adalah adanya persiapan yang dilakukan Balai Diklat Keagamaan Palembang terhadap panitia dengan widyaiswaranya terhadap pelaksanaan pelatihan berbasis e-learning dan juga Balai Diklat Keagamaan Palembang memberikan uang pergantian kuota sehingga peserta pelatihan merasa senang mengikuti pelatihan disamping mendapatkan ilmu pengetahuan juga mendapatkan sertifikat dan ada sedikit pergantian uang pembelian pulsa.

3. Memiliki sikap yang menguntungkan para pengguna terhadap sistem informasi

Untuk point ini Balai Diklat Keagaman Palembang belum memilikinya karena Balai Diklat Keagamaan Palembang belum menyediakan LMS dan buku panduan penggunaan Pelatihan $e-$ learning
4. Tujuan yang akan dicapai dan hubungan timbal balik keuangan untuk oragnisasi

Tujuan dari pelatihan e-lerning sudah disusun sehingga menjadi tolak ukur dalam pelaksanaan pelatihan baik itu bagi widyaiswara, panitia dan peserta pelatihan

\section{PENUTUP}

\section{Simpulan}

Berdasarkan hasil penelitian yang telah dilakukan dapat ditarik kesimpulan

1) Implementasi pelatihan berbasis e-learning melalui empat tahapan yaitu perencanaan, pengorganisasian, pelaksanaan dan evaluasi. Diantara keempat tahapan yang paling baik adalah tahap pelaksanan sedangkan yang perlu dikembangkan adalah perencanaan

2) Faktor penghambat keberhasilan dari pelaksanaan Pelatihan secara berbasis e-learning antara lain jaringan internet, Sumber Daya Manusia (SDM) dan motivasi peserta pelatihan

3) Faktor pendukung keberhasil pelatihan secara berbasis $e$ learning adalah adanya penggantian kuota dari Balai Diklat Keagamaan Palembang. 


\section{Rekomendasi}

Berdasarkan hasil kesimpulan diatas maka penulis memberikan beberapa saran dalam pelaksanaan pelatihan berbasis e-learning adalah

Pembuatan buku panduan pelaksanana pelatihan berbasis $e$ - learning untuk pengajar, panitiadan peserta pelatihan

2. Perbanyak sosialisasi tentang pelaksanana Pelatihan berbasis $e-$ learning 


\section{DAFTAR PUSTAKA}

Anonim. (2018). Peraturan Lembaga Administrasi Negara Republik Indonesia Nomor 12 Tahun 2018 Tentang Pelatihan Dasar Calon Pegawai Negeri Sipil. In Lembaga Administrasi Negara Republik Indonesia (pp. 1-6).

Destiana, B. dan S. (2014). Faktor Determinan Pemanfaatan TIK dan Pengaruhnya terhadap Kinerja Guru di Kabupaten Gunung Kidul.

Irawadi, F dan Yustikarini, L. (2019). Dampak Sertifikasi terhadap Profesionalisme Guru (Studi Pemetaan (PK) GPAI On-Line Tingkat SMA Kota Palembang.

Kamil, M. (2003). Model-Model Pelatihan. Universitas Pendidikan Indonesia.

Lembaga Administrasi Negara. (2018). Peraturan LAN Nomor 8 Tahun 2018.

Mubarak, Z. (2018). Pendidikan di Era Revolusi Industri 4.0 dan Problematika Pendidikan Tinggi.

Peraturan Menteri Agama. (2020). PMA No. 19 Tahun 2020 Tentang Penyelenggaraan Pelatihan SDM di Kementerian Agama.

Tisnawati, E. S. dan S. K. (2012). Pengatar Manajemen. Kencana Prenada Media Group.

Vinet, L., \& Zhedanov, A. (2011). A "missing" family of classical orthogonal polynomials. In Journal of Physics A: Mathematical and Theoretical (Vol. 44, Issue 8). Diambil kembali dari https://doi.org/10.1088/1751-8113/44/8/085201

Wahyuningsih Dian, M. R. (2017). E-Learning Teori dan Aplikasi. Informatika Bandung. 